\title{
Muscarinic Receptor Subtypes in the Lower Urinary Tract
}

\author{
Daniel Giglio Gunnar Tobin
}

Department of Pharmacology, Institute of Neuroscience and Physiology, Sahlgrenska Academy at University of Gothenburg, Gothenburg, Sweden

\section{Key Words}

Muscarinic receptor subtypes $\cdot$ Lower urinary tract •

Physiology $\cdot$ Pathophysiology $\cdot$ Anticholinergic drugs

\begin{abstract}
Acetylcholine acting on muscarinic $\mathrm{M}_{3}$ receptors on the detrusor muscle is the principal stimulus for inducing the contractile response for urinary bladder voiding. The urinary bladder expresses, however, all cloned muscarinic receptor subtypes $\left(M_{1}-M_{5}\right)$. In terms of quantity, the $M_{2}$ subtype dominates over the $M_{3}$ subtype in the detrusor, and its role in contraction seems to be primarily indirect, by blocking stimuli from cAMP-coupled receptors that induce relaxation. The excitatory $M_{1}$ and inhibitory $M_{2}$ and/or $M_{4}$ subtypes are also expressed prejunctionally. Muscarinic $M_{1}$ and $M_{2} / M_{4}$ autoreceptors facilitate and inhibit, respectively, the release of acetylcholine. The urothelium had been considered to be a passive barrier; however, during the last decade, it has been shown that the urothelium is of importance for bladder function. In a state of bladder pathology, muscarinic receptor changes occur in the detrusor, prejunctionally, and in the urothelium, but the character of the change differs between disorders. The urothelium expresses all subtypes of muscarinic receptors, and upon stimulation it releases factors affecting bladder afferents and smooth muscle. During inflammation, the expression of muscarinic $M_{5}$ receptors is increased, particularly in the urothelium, together with a
\end{abstract}

cholinergic-induced production of nitric oxide in the mucosa. The present review describes signalling mechanisms, expression and functional effects of muscarinic receptors in the lower urinary tract. Their roles in physiological and pathophysiological conditions, as well as clinical implications of the occurrence of different muscarinic receptors, are discussed.

Copyright $\odot 2009$ S. Karger AG, Basel

\section{Introduction}

The functions of the urinary bladder are to store urine and to void under voluntary control. The function of the bladder is regulated by an interaction between the somatic, parasympathetic and sympathetic nervous systems. When the bladder volume is below the threshold volume for inducing voiding, the bladder gradually distends and the filling results in only minute rises in intravesical pressure $[1,2]$. When the threshold volume is reached, impulses in afferents are generated through the stimulation of tension receptors in the bladder wall. The impulses are conveyed via afferent myelinated $A \delta$-fibres, principally in the pelvic nerve to the spinal cord, initiating the micturition reflex $[3,4]$. The activation of efferent neurons in the pelvic nerve releasing acetylcholine, which acts on muscarinic receptors on the detrusor muscle, together with an increase in intraabdominal pressure, are

Gunnar Tobin

Department of Pharmacology

PO Box 431

SE-405 30 Göteborg (Sweden)

Tel. +46 31786 3442, Fax +46 31786 3164, E-Mail gunnar.tobin@pharm.gu.se 
the major mediators of the response that may lead to the expulsion of urine [5]. In a state when the parasympathetic input dominates, the sympathetic stimulation is quiescent, leading to relaxation of the internal urethral sphincter. Normally, the micturition is, however, under the control of the individual, since the external sphincter, innervated by the somatic pudendal nerve, relaxes voluntarily and enables bladder voiding.

The muscarinic receptor occurs in 5 subtypes $\left(\mathrm{M}_{1-}\right.$ $\mathrm{M}_{5}$ ) and the fundamental significance of muscarinic $\mathrm{M}_{3}$ receptors for micturition is well established $[6,7]$. Although it has been recognized for a long period of time that other subtypes of the receptor can be found on smooth muscle cells, when examined morphologically, the functional significance of the different receptor subtypes has not been fully unravelled. It is well known that the subtypes of the receptor population interact on neuronal as well as on non-neuronal cells in the regulation of autonomic responses [8-10]. Lately, however, muscarinic receptors have also been suggested to be implicated in the control of inflammation, cell growth and proliferation [11-17].

The muscarinic receptors belong to the family of Gprotein-coupled receptors [18]. The $G$ proteins, consisting of one $\alpha$-, $\beta$ - and $\gamma$-subunit, are subdivided into $G_{s}$, $\mathrm{G}_{\mathrm{i} / \mathrm{o}}, \mathrm{G}_{\mathrm{q}}$ and $\mathrm{G}_{12}$ depending on the primary sequence homology of their $\alpha$-subunits [19]. The muscarinic receptor subtypes couple differentially to the $G$ proteins, and the subunits of $G$ proteins activate distinct cellular pathways. Preferentially, the inhibitory muscarinic $\mathrm{M}_{2}$ and $\mathrm{M}_{4}$ receptors couple to $G_{i / o}$, whereas the excitatory muscarinic $M_{1}, M_{3}$ and $M_{5}$ receptors preferentially couple to $G_{q / 11}$ [20]. The inhibitory muscarinic $\mathrm{M}_{2}$ and $\mathrm{M}_{4}$ receptors may also affect adenylate cyclase activity, prolong the opening of potassium, as well as that of non-selective cation channels and transient receptor potential channels [21]. Muscarinic $M_{1}, M_{3}$ and $M_{5}$ receptors, on the other hand, increase intracellular calcium by mobilizing phosphoinositides that generate InsP3 (inositol 1,4,5-trisphosphate) and DAG (1,2-diacylglycerol) [17,22].

\section{The Lower Urinary Tract}

\section{Innervation}

The detrusor smooth muscle cells are supplied by an abundant quantity of autonomic nerve fibres. Animal studies show a rich innervation of cholinergic nerves in the detrusor, while noradrenergic nerves appear relatively sparse [23]. Similarly, the autonomic nerves in the hu- man bladder contain choline acetyltransferase, and electron microscopy has demonstrated that the majority of axonal varicosities in close proximity to detrusor smooth muscle have features of cholinergic nerve terminals [2426]. As in other species, the detrusor muscle of the human bladder is sparsely supplied with sympathetic nerve fibres [27]. Clusters of autonomic cells populate the bladder wall, most numerously in the adventitia. The choline acetyltransferase-containing neurons, and therefore presumably cholinergic neurons, receive excitatory inputs from pre-ganglionic cholinergic nerve terminals and inhibitory signals from noradrenergic nerve terminals [28]. Also, the urethral internal sphincter is innervated by cholinergic and noradrenergic nerve fibres [27, 29].

\section{Detrusor}

The contraction of the urinary bladder is primarily dependent on the activation of muscarinic receptors. In the urinary bladders of different species, including man, mRNAs for all 5 muscarinic receptor subtypes are expressed [30, 31]. In the human detrusor, Mansfield et al. [32] reported that of the total muscarinic receptor population, $70 \%$ were of the $M_{2}$ subtype, $20 \%$ of the $M_{3}$ subtype and $10 \%$ of the $M_{1}$ subtype. The dominance of muscarinic $\mathrm{M}_{2}$ receptors is consistently reported. So, the ratio between muscarinic $\mathrm{M}_{2}$ and $\mathrm{M}_{3}$ receptors in binding studies has been estimated as 9:1 and 3:1 in rats and humans, respectively $[33,34]$. Although in the minority, in several functional and knockout studies, the muscarinic $\mathrm{M}_{3}$ receptors have been linked with the entire or almost the entire cholinergic contractile response of the bladder [3541]. Also, the muscarinic $M_{3}$ receptors induce the major part of the hydrolysis of phosphoinositide in the bladder [42]. However, the muscarinic $\mathrm{M}_{5}$ receptor protein closely resembles the protein of the muscarinic $\mathrm{M}_{3}$ receptor [43], and its pharmacological effect is hard to discriminate from that of other excitatory muscarinic receptors, particularly the $\mathrm{M}_{3}$ subtype $[44,45]$. Nevertheless, muscarinic $M_{3}$ receptors may mobilize calcium by different pathways in the bladder; in the human bladder, by extracellular calcium through nifedipine-sensitive calcium channels and by activation of a Rho kinase [46]. Although muscarinic $\mathrm{M}_{3}$ receptors are principally responsible for the bladder contraction, in vivo knockout studies have revealed that muscarinic $\mathrm{M}_{2}$ receptors may have direct but small contractile effects [38]. However, prerequisites for direct muscarinic $\mathrm{M}_{2}$ receptor involvement in contraction are inactivated muscarinic $\mathrm{M}_{3}$ receptors and high levels of intracellular cAMP $[34,47]$. Still, the predominant effect of the muscarinic $\mathrm{M}_{2}$ receptors is indirect, facilitating 
contractions by opposing relaxations induced by adenylate-cyclase-coupled receptors such as the $\beta$-adrenoceptors and $\mathrm{P}_{1}$ purinoceptors [35, 48-54] (fig. 1). Cross-talks between muscarinic $M_{2}$ and $M_{3}$ receptors in the regulation of second messengers and extracellular signal-regulated kinase activity have been demonstrated in muscarinic transfected $\mathrm{CHO}$ cells [55]. The functional effects of the muscarinic $\mathrm{M}_{2}$ receptors in the urinary bladder seem to be difficult to discern, since cystometric studies demonstrate that muscarinic $\mathrm{M}_{2}$ receptor knockout mice have normal micturition parameters [39]. Also, muscarinic receptors seem to affect neuronal nitric oxide (NO) synthase activity, as shown in the rat urinary bladder [56]. Even though NO may modulate bladder responses and seems to be responsible for the main part of the inhibitory non-adrenergic non-cholinergic responses in the lower urinary tract, its functional role in the normal bladder is not established [57]. It has been suggested that NO may be an important factor for relaxation during the filling phase $[58,59]$. The efferent limb in the relaxatory loop, in which NO is the last link, seems to be the hypogastric nerve [60]. The release of noradrenaline is thus suggested to induce production of NO.

In the urinary bladder, prejunctional muscarinic receptors modify the release of acetylcholine into the synaptic clefts by excitatory muscarinic $\mathrm{M}_{1}$ and inhibitory $\mathrm{M}_{2}$ or $\mathrm{M}_{4}$ receptors [40,61-65]. In view of the low specificity of the pharmacological tools used in several of the studies, the characterization of either muscarinic $\mathrm{M}_{2}$ or $\mathrm{M}_{4}$ receptors must be considered indecisive. Experiments on the urinary bladder in knockout mice show that the inhibitory autoreceptor is of the muscarinic $\mathrm{M}_{4}$ receptor subtype [66]. Nevertheless, the inhibitory modulation preferentially occurs at low-intensity nerve activity, whereas, with intense activity, short-lasting facilitator modulation occurs [67]. Also, NO affects the release of acetylcholine by inhibition, as indicated by examinations of the female rabbit bladder [68]. Interactions between the parasympathetic and sympathetic nervous systems have also been demonstrated in the bladder, i.e. inhibitory muscarinic receptors located on adrenergic nerve terminals inhibit the release of noradrenaline in the rabbit bladder and urethra [69-71]. In the rabbit urinary bladder, $\alpha_{2}$-adrenoceptors also inhibit the release of acetylcholine [67].

\section{Urothelium}

The urothelium functions as a barrier against entry of pathogens, water, ions, solutes and macromolecules into the underlying tissue [72-74]. Even if the barrier function

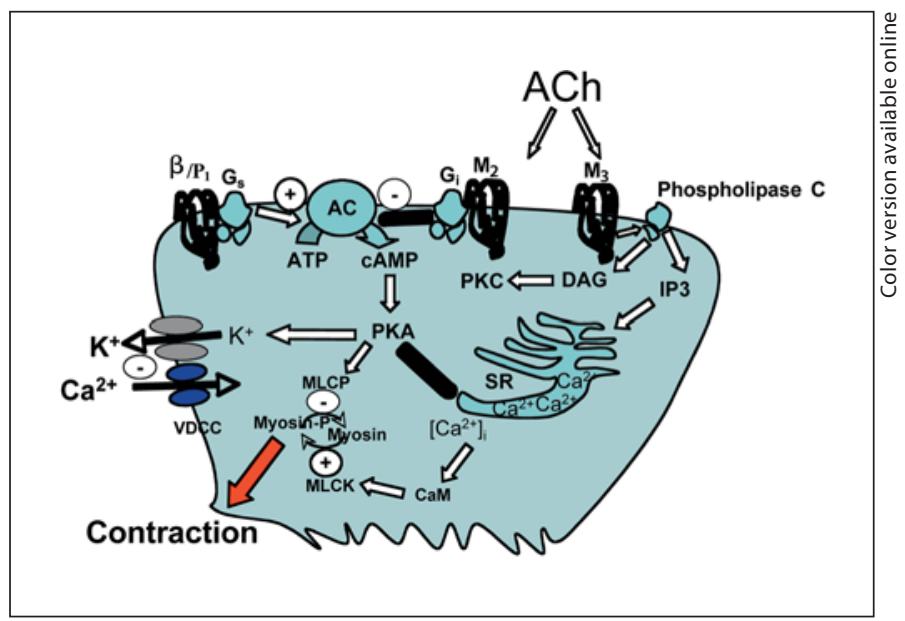

Fig. 1. Acetylcholine (ACh) control of contraction in a smooth muscle cell. ACh binds to the G-protein-linked muscarinic $\mathrm{M}_{3}$ and $\mathrm{M}_{2}$ receptors. The muscarinic $\mathrm{M}_{3}$ receptor causes phospholipase $\mathrm{C}$ to generate IP3. IP3 binds to and opens the IP3 receptor on the endoplasmic reticulum, which releases $\mathrm{Ca}^{2+}$. Calmodulin $(\mathrm{CaM})$ undergoes a conformational change upon binding to calcium, which enables it to activate the myosin light chain kinase (MLCK)-dependent pathway and induce contraction. The muscarinic $\mathrm{M}_{2}$ receptor inhibits generation of cAMP; the cAMP pathway activates protein kinase A (PKA), which leads to inhibition of contraction. Lines ending with an arrow indicate stimulatory effects and lines with a round ending indicate inhibitory effects. $\mathrm{AC}=$ Adenylate cyclase $\mathrm{PKC}=$ protein kinase $\mathrm{C}$; $\mathrm{SR}=$ sarcoplasmatic reticulum; MLCP = myosin light chain phosphatase; VDCC = voltage-dependent calcium channel.

is important, the urothelium possesses several other dynamic qualities. The urothelial cells express several types of receptors, and stimulation of these receptors may cause release of substances affecting detrusor function $[75,76]$. The porcine urothelium expresses a high density of muscarinic receptors, even higher than the bladder smooth muscle [77], and, in the rat and human urothelium, the receptor proteins and mRNAs, respectively, for all muscarinic receptor subtypes $\left(\mathrm{M}_{1}-\mathrm{M}_{5}\right)$ occur $[31,78]$. However, the expression pattern seems to vary for the different subtypes. Principally in the human urothelium, the $M_{1}$ receptors were reported to occur on basal cells, $M_{2}$ on umbrella cells, $M_{3}$ and $M_{4}$ homogenously and $M_{5}$ with a decreasing gradient from luminal to basal cells [79]. Mansfield et al. [32] revealed by RT-PCR analysis an abundant expression of muscarinic $\mathrm{M}_{2}$ receptors in the human bladder mucosa, but the receptors may occur at other locations in humans also, e.g. on myofibroblast-like cells [80]. 


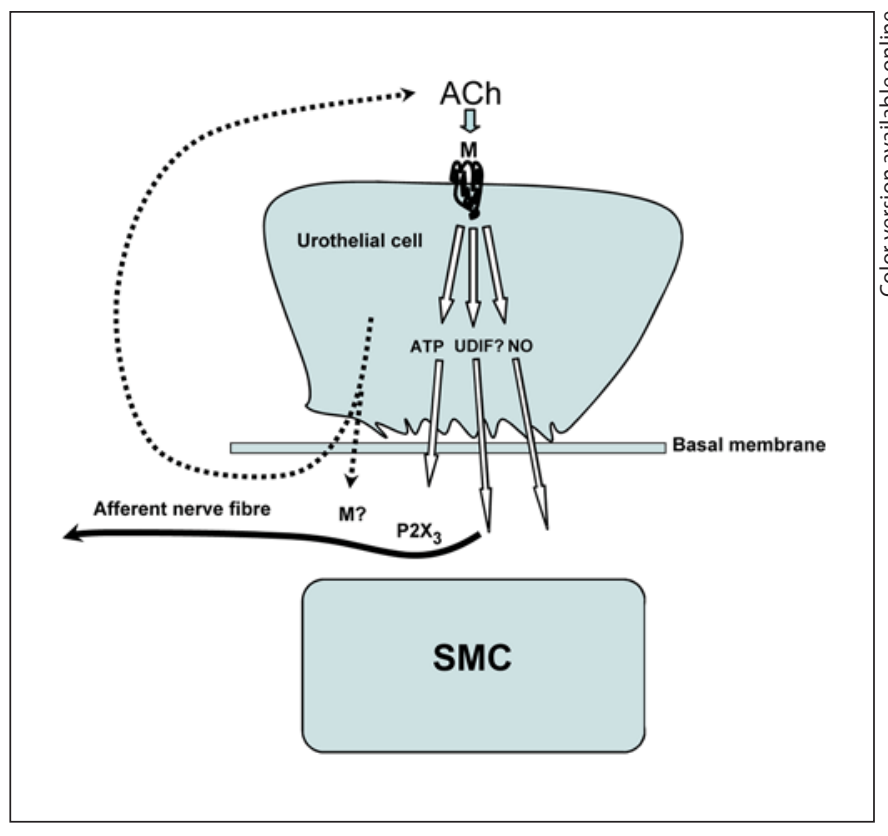

Fig. 2. Indirect acetylcholine (ACh) effects on detrusor cells via urothelial cell function. ACh has been suggested to induce urothelial release of ATP, urothelial-derived unidentified factors (UDIF) and NO. SMC = Smooth muscle cells.

Because of the proximity of the suburothelial nerve plexus to the urothelium [81-84], the urothelium is suggested to work as a mechanosensory conductor, e.g. in response to distension, it releases adenosine- $5^{\prime}$-triphosphate (ATP) affecting underlying afferent nerve fibres via purinoceptors [85-87] (fig. 2). Furthermore, stimulation of urothelial muscarinic receptors induces release of ATP, which may consequently modify the afferent response of the bladder $[88,89]$. Acetylcholine is also produced in the urothelium, but the mechanism behind its release from the urothelium does not seem to involve vesicular exocytosis, which seems to be a general feature of non-neuronal release [90-92]. The organic cation transporter 3 subtype has been suggested to be involved in the non-neuronal release and to occur in the rat urothelium $[92,93]$. A muscarinic receptor negative feedback mechanism on acetylcholine release was also described in the urothelium.

Notably, it has been suggested from in vitro studies that stimulation of muscarinic receptors in the mucosa induces the release of an unidentified potent relaxatory factor, which presumably is neither NO nor a product of the cyclooxygenase pathway, affecting the contractile response of the porcine and human bladder $[77,94]$. During in vitro studies of the rat bladder, a cholinergic-induced release of a relaxant factor also occurs, but it does not seem to be released from the mucosa $[95,96]$. In confirmation, during in vivo examinations at our laboratory, the removal of the mucosa did not change the cholinergic contractile bladder response of the normal rat [97]. However, it remains to be established whether this unidentified factor is just one factor or several, and, further, whether the factor(s) is released from the urothelium or from other parts of the mucosa.

\section{The Urethra}

The muscarinic receptors are also present in the urethra, but their functions have not been clarified [24, 57, 98]. The urethral sphincter tone is predominantly regulated by adrenergic nerves, but muscarinic receptors also modulate the tone [57, 98-102]. Muscarinic receptor activation mediates constriction of the urethra, but also induces urethral relaxation by the release of NO [103-105]. It seems that these two cholinergic effects are site dependent, i.e. the muscarinic receptor mediates contraction of the proximal urethra whilst mediating relaxation of the distal urethra through the release and actions of NO [101, 103]. In the pig, cholinergic urethral constriction seems to be mediated by both the muscarinic $\mathrm{M}_{2}$ and $\mathrm{M}_{3}$ receptor subtypes [47]. The authors reported that there seem to be differences according to the circular and the longitudinal urethral layers. Namely, muscarinic stimulation exerted considerably larger contractile responses from the longitudinal muscle than from the circular, and, further, that muscarinic $\mathrm{M}_{2}$ receptors mostly occurred in the circular muscle layers and muscarinic $\mathrm{M}_{3}$ receptors in the longitudinal layer. Tentatively, this could indicate an urethral stabilizing and widening function of the cholinergic response during micturition; a longitudinal muscle contraction resulting in a shorter and possibly wider urethra.

\section{Pathophysiological and Trophic Effects}

During pathological conditions of the urinary bladder, changes in the afferent as well as efferent nervous pathways occur [106-108]. Since muscarinic receptors play a predominant role in the contraction of the bladder, several studies have assessed the cholinergic function in bladder pathology. Denervation and decentralization induce super-sensitivity to cholinergic stimuli, as been observed in the rat bladder [109], which also occurs after capsaicin treatment [110]. In the denervated rat bladder 
and in the bladder of spinal cord-injured rats, the expression of muscarinic $\mathrm{M}_{2}$ receptors increases [111-113], while, in diabetic rats, a super-sensitivity to cholinergic stimuli occurs concomitantly with increments in muscarinic receptor density and in muscarinic $\mathrm{M}_{3}$ receptor expression [114-116]. Modulations in the cholinergic bladder contraction also occur during cystitis $[78,108]$. The muscarinic $M_{1}$ and $M_{5}$ receptors are upregulated, particularly in the urothelium, which seems to be coupled to the synthesis and release of NO [78, 97, 117]. Changes in the expression of muscarinic receptor subtypes can also be induced in a urothelial cell line by the pro-inflammatory substance acrolein found in the bladder [118]. Upregulation of muscarinic receptors, as well as a parasympathetic sprouting arising in the mucosa, occur during cyclophosphamide-induced cystitis [119]. This may reflect compensatory mechanisms, as the changes in cystitis from prejunctional muscarinic receptor effects might also [120]. In chronic spinal cord injury, a prejunctional change in the muscarinic $M_{1}, M_{2}$ and $M_{3}$ receptor expression may be induced [121], as well as augmentation of cholinergic-induced release of ATP from the urothelium [122], and, notably, increases in muscarinic receptor expression at a non-neuronal level occur on suburothelial myofibroblast-like cells during detrusor overactivity and painful bladder syndrome [80]. The character of the expression changes thus varies according to the type of disorder. Research interest has so far mainly addressed the muscarinic $\mathrm{M}_{2}$ and $\mathrm{M}_{3}$ receptor subtypes in bladder disorders, while other subtypes, particularly of non-smooth muscle origin, have been overlooked or their roles are difficult to investigate.

In several species, such as the rat and the guinea pig, an atropine-resistant part of the bladder contraction exists (constituting more than $50 \%$ of the contraction [123126]), while it is small or absent in the human bladder $[127,128]$. The atropine-resistant part of the contraction is largely mediated by ATP $[129,130]$. In man, ATP seems to mediate this response also $[131,132]$, even though other mechanisms have been suggested [133]. In the rat, the bladder contraction consists of a phasic and a tonic component in which ATP and acetylcholine play predominant roles, respectively $[120,134,135]$. In vivo studies of the rat reveal that both transmitters are important for emptying the bladder [134]. However, a postjunctional interaction between the cholinergic and the purinergic systems seems to occur; the activation of either contractile system results in a reduction in the other $[48,136]$. In the bladder of diabetic rats, the cholinergic part of the parasympathetic response is decreased [137]. Conversely, other reports on partial bladder outlet obstruction and cystitis in the rat show that the atropine-sensitive part of bladder contraction is not affected or even increased [78, 138]. In man also, the non-cholinergic contractile effect increases in the functionally disturbed bladder [139]. All studies, performed in different species and during different disorders and conditions, indicate that the muscarinic receptor expression and functions may be conspicuously altered. Furthermore, in pathological conditions, NO seems to be an important molecule in the lower urinary tract [107], and seems to be of pivotal significance in interstitial cystitis [140]. In inflammation, muscarinic receptors have been suggested to couple to endothelial NO synthase activity [78], and muscarinic receptors seem to induce release of $\mathrm{NO}$ from the mucosa, as demonstrated in urothelium-denuded rats [97]. In view of the increased muscarinic receptor expression during cystitis, and, further, since muscarinic receptors have been shown to promote growth of tumour cells in several tissues $[13,78$, 141-144], the regulation of the muscarinic receptor expression may have a role in the tumour biology of bladder cancer. To exemplify, in prostate cancer, the degree of differentiation is strongly correlated to the expression of muscarinic $\mathrm{M}_{3}$ receptors [144].

\section{Clinical Aspects}

Drugs affecting muscarinic receptors have been used frequently and for a long time for treatment of diseases in the lower urinary tract. Generally, cholinergic treatments are nowadays no longer the first choice of treatment, with the exception of the urinary bladder, where anticholinergic treatments may still be used $[145,146]$. Medical trials on anticholinergic treatment against overactive bladder have revealed that the placebo effect contributes markedly (by $30-50 \%$ ) to the clinical improvement of patients [147]. Long-term studies on detrusor instability/overactive bladder have revealed that the 'subtype-selective' drugs of today do not have any better effect on the condition than traditional drugs $[148,149]$. Even if their efficacy seems to be comparable, 'subtype-selective' drugs have fewer side effects than traditional drugs $[147,150]$. Traditionally, anticholinergic treatment of overactive bladder has been considered to mediate its clinical effect by blocking muscarinic receptors on the detrusor and inhibiting contraction evoked by acetylcholine released from the parasympathetic innervation. At therapeutic doses, the anticholinergic drugs do not seem to inhibit the detrusor contractility $[151,152]$. Instead, muscarinic 
Fig. 3. Schematic figure illustrating the principal occurrence and potential roles of muscarinic receptor subtypes in the urinary bladder. The filling of the bladder eventually results in a stretch of the urothelial cells causing release of acetylcholine $(\mathrm{ACh})$. $\mathrm{ACh}$ induces production of urothelial factors, such as ATP, which may excite afferents for example. Efferent nerve fibres release acetylcholine. The release may be facilitated and inhibited by muscarinic $\mathrm{M}_{1}$ and $\mathrm{M}_{4}$ autoreceptors, respectively. The detrusor muscle is stimulated to contract by muscarinic $\mathrm{M}_{3}$ receptors. Muscarinic $\mathrm{M}_{2}$ receptors counteract relaxatory stimulus (e.g. $\beta$-adrenoceptor) acting on the muscle cell.

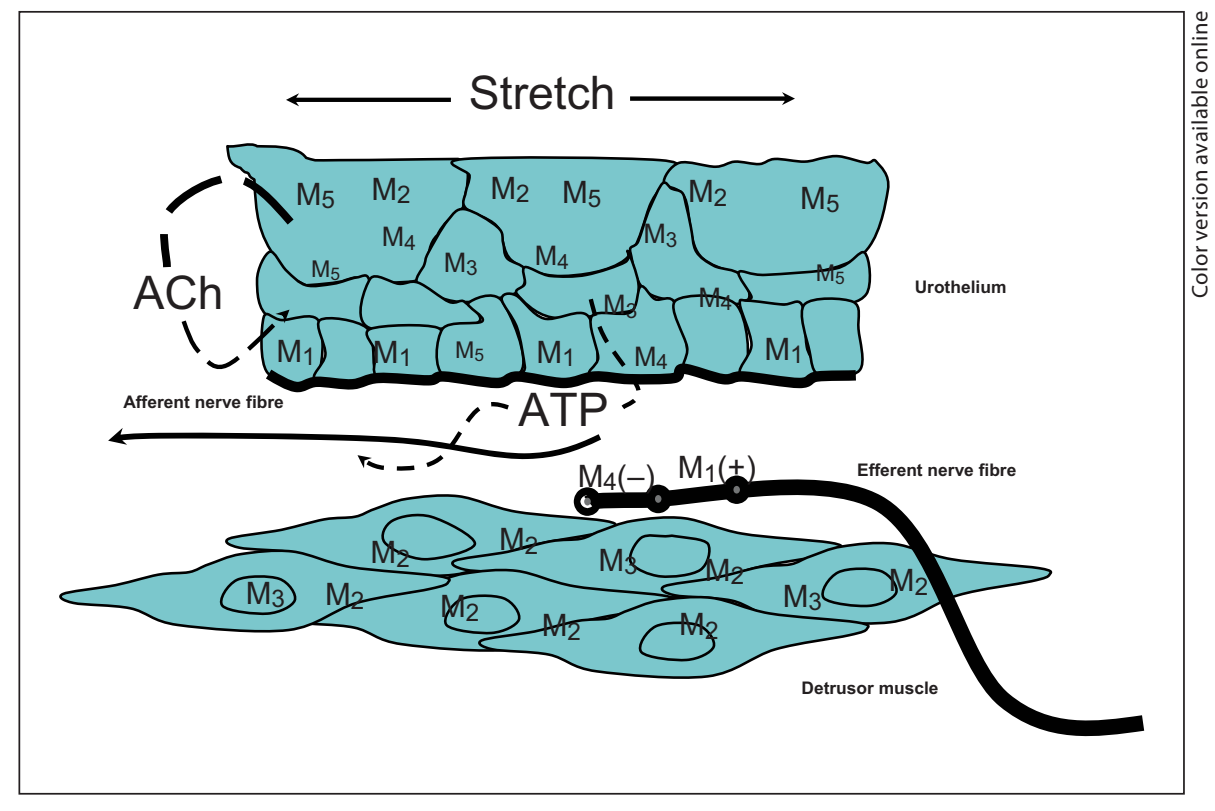

antagonists are considered to act mainly during the filling phase, and to increase bladder capacity and decrease urgency. It has been hypothesized that the antagonists act by blocking urothelial muscarinic receptors, and by that inhibiting the effects of non-neuronal acetylcholine on the release of other urothelial substances, such as ATP [153]. Still, a muscarinic $\mathrm{M}_{3}$-selective profile is advantageous in order to avoid cardiac, cerebral and possibly glandular side effects [154-160]. In spite of a $\mathrm{M}_{3}$-selective profile, many anticholinergics are only capable of discriminating the human muscarinic $\mathrm{M}_{3}$ subtype from the $M_{1}$ and $M_{5}$ subtypes with an affinity factor of 1-16 [161164]. The common side effect of anticholinergic therapy against overactive bladder is a dry mouth $[149,165]$, and, since muscarinic $M_{1}$ receptors exert secretory effects, muscarinic $\mathrm{M}_{3}$ receptor-selective antagonists would tentatively result in fewer incidences of this adverse effect $[150,166,167]$.

Studies show that muscarinic receptor changes in the urothelium, as mentioned previously, may be of importance in the development of bladder disorders, i.e. in the inflamed urinary bladder and the urothelium of diabetic rats, an increased expression of muscarinic receptors occurs $[78,168]$. In view of the expression of muscarinic receptors in the urothelium/afferent nerves, studies have suggested that these receptors may constitute specific targets for medical treatments against an overactive bladder [31, 169]. A precondition for effect does not nec- essarily have to be muscarinic receptor subtype selectivity, but could be achieved by local administration of atropine and oxybutynin, as shown in an animal model as well as in patients [170-172]. Evidence for a coupling between muscarinic receptors and $\mathrm{C}$ fibres in the bladder has been put forward, i.e. tolterodine increases bladder capacity when it is intravesically administered, and the increase is attenuated by $\mathrm{C}$ fibre desensitization [173]. In conclusion, the efficacy of an anticholinergic drug may depend on several factors, such as muscarinic receptorbinding profile, membrane permeability and urinal active metabolites. Irrespective of the kind of disease being treated with drugs acting upon muscarinic receptors, better efficacy and less adverse effects are desirable. Muscarinic receptor subtype-selective drugs may achieve this.

\section{Concluding Comments}

In the urinary bladder, muscarinic $\mathrm{M}_{3}$ receptors are the principal receptor for detrusor contraction, but muscarinic $\mathrm{M}_{2}$ receptors may enhance contractions mainly by inhibition of detrusor relaxation (figure 3 indicates in a schematic illustration the expression of receptors in bladder tissues). The heterogeneous muscarinic receptor population of the urothelium/suburothelium is altered during inflammation, and in particular the expression of 
muscarinic $\mathrm{M}_{5}$ receptors is upregulated. Alterations in the muscarinic receptor signalling systems contribute to the pathogenesis of disorders of the functions reviewed here, including changes in acute responses and after the induction of inflammation. In view of muscarinic recep- tors being involved in many functions in different tissues besides the urinary bladder, knowledge about the specific receptor subtype involved in the responses provides prerequisites for effective drug treatments against bladder disorders with fewer adverse effects in the future.

\section{References}

1 Torrens M, Morrison JFB: The Physiology of the Lower Urinary Tract. Heidelberg, Springer, 1987.

2 Walsh PC, Retik AB, Vaughan ED Jr, Wein AJ: Campbell's Urology. Philadelphia, Elsevier, 2002.

-3 Andersson KE: Bladder activation: afferent mechanisms. Urology 2002;59:43-50.

4 Morrison J: The activation of bladder wall afferent nerves. Exp Physiol 1999;84:131-136.

5 Hemat RAS: Principles of Modern Urology. Blackrock, Urotext, 2003.

6 Uchiyama T, Chess-Williams R: Muscarinic receptor subtypes of the bladder and gastrointestinal tract. J Smooth Muscle Res 2004; 40:237-247.

7 Lecci A, Santicioli P, Maggi CA: Pharmacology of transmission to gastrointestinal muscle. Curr Opin Pharmacol 2002;2:630-641.

-8 Unno T, Matsuyama H, Izumi Y, Yamada M, Wess J, Komori S: Roles of $\mathrm{M}_{2}$ and $\mathrm{M}_{3}$ muscarinic receptors in cholinergic nerve-induced contractions in mouse ileum studied with receptor knockout mice. Br J Pharmacol 2006;149:1022-1030.

-9 Somogyi GT, de Groat WC: Function, signal transduction mechanisms and plasticity of presynaptic muscarinic receptors in the urinary bladder. Life Sci 1999;64:411-418.

10 Tobin G, Giglio D, Lundgren O: Muscarinic receptor subtypes in the alimentary tract. J Physiol Pharmacol 2009, in press.

-11 Casanova MF, Trippe J 2nd: Regulatory mechanisms of cortical laminar development. Brain Res Rev 2006;51:72-84.

12 Ventura S, Pennefather J, Mitchelson F: Cholinergic innervation and function in the prostate gland. Pharmacol Ther 2002;94:93112.

13 Ukegawa JI, Takeuchi Y, Kusayanagi S, Mitamura K: Growth-promoting effect of muscarinic acetylcholine receptors in colon cancer cells. J Cancer Res Clin Oncol 2003;129: 272-278.

- 14 Profita M, Giorgi RD, Sala A, Bonanno A, Riccobono L, Mirabella F, Gjomarkaj M, Bonsignore G, Bousquet J, Vignola AM: Muscarinic receptors, leukotriene $\mathrm{B}_{4}$ production and neutrophilic inflammation in COPD patients. Allergy 2005;60:1361-1369.

15 Racke K, Juergens UR, Matthiesen S: Control by cholinergic mechanisms. Eur J Pharmacol 2006;533:57-68.
6 Kawashima K, Fujii T: Expression of nonneuronal acetylcholine in lymphocytes and its contribution to the regulation of immune function. Front Biosci 2004;9:2063-2085.

17 van Koppen CJ, Kaiser B: Regulation of muscarinic acetylcholine receptor signaling. Pharmacol Ther 2003;98:197-220.

18 Lanzafame AA, Christopoulos A, Mitchelson F: Cellular signaling mechanisms for muscarinic acetylcholine receptors. Receptors Channels 2003;9:241-260.

19 Guderman T, Kalkbrenner F, Schultz G: Diversity and selectivity of receptor G-protein interaction. Annu Rev Pharmacol Toxicol 1996;36:429-459.

20 Wu G, Bogatkevich GS, Mukhin YV, Benovic JL, Hildebrandt JD, Lanier SM: Identification of $G \beta \gamma$ binding sites in the third intracellular loop of the $\mathrm{M}_{3}$-muscarinic receptor and their role in receptor regulation. J Biol Chem 2000;275:9026-9034.

21 Zholos AV, Zholos AA, Bolton TB: G-protein-gated TRP-like cationic channel activated by muscarinic receptors: effect of potential on single-channel gating. J Gen Physiol 2004;123:581-598.

22 Lucas JL, Wang D, Sadee W: Calmodulin binding to peptides derived from the i3 loop of muscarinic receptors. Pharm Res 2006;23: 647-653.

$\checkmark 23$ Gosling JA, Dixon JS: The structure and innervation of smooth muscle in the wall of the bladder neck and proximal urethra. Br J Urol 1975;47:549-558.

24 Ek A, Alm P, Andersson KE, Persson CG: Adrenergic and cholinergic nerves of the human urethra and urinary bladder: a histochemical study. Acta Physiol Scand 1977;99: 345-352.

25 Alm P: Cholinergic innervation of the human urethra and urinary bladder: a histochemical study and review of methodology. Acta Pharmacol Toxicol (Copenh) 1978; 43(suppl 2):56-62.

26 Kluck P: The autonomic innervation of the human urinary bladder, bladder neck and urethra: a histochemical study. Anat Rec 1980;198:439-447.

27 Gosling JA: The distribution of noradrenergic nerves in the human lower urinary tract. Clin Sci (Lond) 1986;70(suppl 14):s3-s6.
28 de Groat WC, Booth AM: Inhibition and facilitation in parasympathetic ganglia of the urinary bladder. Fed Proc 1980;39:29902996.

29 Gosling JA, Dixon JS, Lendon RG: The autonomic innervation of the human male and female bladder neck and proximal urethra. J Urol 1977;118:302-305.

-30 Sigala S, Mirabella G, Peroni A, Pezzotti G, Simeone C, Spano P, Cunico SC: Differential gene expression of cholinergic muscarinic receptor subtypes in male and female normal human urinary bladder. Urology 2002; 60:719-725

-31 Tyagi S, Tyagi P, Van-le S, Yoshimura N, Chancellor MB, de Miguel F: Qualitative and quantitative expression profile of muscarinic receptors in human urothelium and detrusor. J Urol 2006;176:1673-1678.

- 32 Mansfield KJ, Liu L, Mitchelson FJ, Moore $\mathrm{KH}$, Millard RJ, Burcher E: Muscarinic receptor subtypes in human bladder detrusor and mucosa, studied by radioligand binding and quantitative competitive RT-PCR: changes in ageing. Br J Pharmacol 2005; 144 : 1089-1099.

33 Wang P, Luthin GR, Ruggieri MR: Muscarinic acetylcholine receptor subtypes mediating urinary bladder contractility and coupling to GTP binding proteins. J Pharmacol Exp Ther 1995;273:959-966.

34 Yamanishi T, Chapple CR, Yasuda K, ChessWilliams R: The role of $\mathrm{M}_{2}$-muscarinic receptors in mediating contraction of the pig urinary bladder in vitro. Br J Pharmacol 2000;131:1482-1488.

35 Hegde SS, Choppin A, Bonhaus D, Briaud S, Loeb M, Moy TM, Loury D, Eglen RM: Functional role of $\mathrm{M}_{2}$ and $\mathrm{M}_{3}$ muscarinic receptors in the urinary bladder of rats in vitro and in vivo. Br J Pharmacol 1997;120:14091418 .

36 Mimata H, Nomura Y, Emoto A, Latifpour J, Wheeler M, Weiss RM: Muscarinic receptor subtypes and receptor-coupled phosphatidylinositol hydrolysis in rat bladder smooth muscle. Int J Urol 1997;4:591-596.

37 Chess-Williams R, Chapple CR, Yamanishi T, Yasuda K, Sellers DJ: The minor population of $\mathrm{M}_{3}$-receptors mediate contraction of human detrusor muscle in vitro. J Auton Pharmacol 2001;21:243-248. 
-38 Matsui M, Motomura D, Fujikawa T, Jiang J, Takahashi S, Manabe T, Taketo MM: Mice lacking $\mathrm{M}_{2}$ and $\mathrm{M}_{3}$ muscarinic acetylcholine receptors are devoid of cholinergic smooth muscle contractions but still viable. J Neurosci 2002;22:10627-10632.

-39 Igawa Y, Zhang X, Nishizawa O, Umeda M, Iwata A, Taketo MM, Manabe T, Matsui M, Andersson KE: Cystometric findings in mice lacking muscarinic $\mathrm{M}_{2}$ or $\mathrm{M}_{3}$ receptors. J Urol 2004; 172:2460-2464.

40 Tobin G, Sjogren C: In vivo and in vitro effects of muscarinic receptor antagonists on contractions and release of $\left[{ }^{3} \mathrm{H}\right]$ acetylcholine in the rabbit urinary bladder. Eur J Pharmacol 1995;281:1-8.

-41 Longhurst PA, Leggett RE, Briscoe JA: Characterization of the functional muscarinic receptors in the rat urinary bladder. Br J Pharmacol 1995;116:2279-2285.

-42 Tran JA, Matsui M, Ehlert FJ: Differential coupling of muscarinic $\mathrm{M}_{1}, \mathrm{M}_{2}$, and $\mathrm{M}_{3}$ receptors to phosphoinositide hydrolysis in urinary bladder and longitudinal muscle of the ileum of the mouse. J Pharmacol Exp Ther 2006;318:649-656.

43 Bonner TI, Young AC, Brann MR, Buckley NJ: Cloning and expression of the human and rat $\mathrm{M}_{5}$ muscarinic acetylcholine receptor genes. Neuron 1988;1:403-410.

44 Eglen RM, Choppin A, Watson N: Therapeutic opportunities from muscarinic receptor research. Trends Pharmacol Sci 2001;22: 409-414.

-45 Watson N, Daniels DV, Ford AP, Eglen RM, Hegde SS: Comparative pharmacology of recombinant human $\mathrm{M}_{3}$ and $\mathrm{M}_{5}$ muscarinic receptors expressed in $\mathrm{CHO}-\mathrm{K} 1$ cells. $\mathrm{Br} \mathrm{J}$ Pharmacol 1999;127:590-596.

-46 Schneider T, Fetscher C, Krege S, Michel MC: Signal transduction underlying carbachol-induced contraction of human urinary bladder. J Pharmacol Exp Ther 2004;309: 1148-1153.

-47 Yamanishi T, Chapple CR, Yasuda K, ChessWilliams R: The role of $\mathrm{M}_{2}$ muscarinic receptor subtypes in mediating contraction of the pig bladder base after cyclic adenosine monophosphate elevation and/or selective $\mathrm{M}_{3}$ inactivation. J Urol 2002;167:397-401.

48 Giglio D, Delbro DS, Tobin G: On the functional role of muscarinic $\mathrm{M}_{2}$ receptors in cholinergic and purinergic responses in the rat urinary bladder. Eur J Pharmacol 2001; 428:357-364.

49 Ma FH, Higashira-Hoshi H, Itoh Y: Functional muscarinic $\mathrm{M}_{2}$ and $\mathrm{M}_{3}$ receptors and beta-adrenoceptor in cultured rat bladder smooth muscle. Life Sci 2002;70:1159-1172.

50 Hegde SS, Eglen RM: Muscarinic receptor subtypes modulating smooth muscle contractility in the urinary bladder. Life Sci 1999;64:419-428.

\section{Matsui M, Griffin MT, Shehnaz D, Taketo MM, Ehlert FJ: Increased relaxant action of forskolin and isoproterenol against mus- carinic agonist-induced contractions in smooth muscle from $\mathrm{M}_{2}$ receptor knockout mice. J Pharmacol Exp Ther 2003;305:106-} 113.

52 Ehlert FJ, Griffin MT, Abe DM, Vo TH, Taketo MM, Manabe T, Matsui M: The $\mathrm{M}_{2}$ muscarinic receptor mediates contraction through indirect mechanisms in mouse urinary bladder. J Pharmacol Exp Ther 2005. 313:368-378.

53 Furuno T, Kakizaki H, Tanaka H, Mitsui T, Nonomura K: Enhanced inhibitory effects of beta-adrenoceptor agonist on cholinergic micturition contractions in muscarinic $\mathrm{M}_{2}$ receptor knockout mice. Int Continence Soc Meet, Christchurch, 2006.

54 Giglio D, Delbro DS, Tobin G: Postjunctional modulation by muscarinic $\mathrm{M}_{2}$ receptors of responses to electrical field stimulation of rat detrusor muscle preparations. Auton Autacoid Pharmacol 2005;25:113-120.

55 Hornigold DC, Mistry R, Raymond PD, Blank JL, Challiss RA: Evidence for crosstalk between $\mathrm{M}_{2}$ and $\mathrm{M}_{3}$ muscarinic acetylcholine receptors in the regulation of second messenger and extracellular signal-regulated kinase signalling pathways in Chinese hamster ovary cells. Br J Pharmacol 2003; 138:1340-1350.

56 Orman B, Sterin-Borda L, Reina S, Borda ES: Neuronal nitric oxide synthase activity in rat urinary bladder detrusor: participation in $\mathrm{M}_{3}$ and $\mathrm{M}_{4}$ muscarinic receptor function. Auton Autacoid Pharmacol 2005;25:93-100.

57 Andersson KE, Wein AJ: Pharmacology of the lower urinary tract: basis for current and future treatments of urinary incontinence. Pharmacol Rev 2004;56:581-631.

58 James MJ, Birmingham AT, Hill SJ: Partial mediation by nitric oxide of the relaxation of human isolated detrusor strips in response to electrical field stimulation. Br J Clin Pharmacol 1993;35:366-372.

59 Theobald RJ Jr: The effect of $\mathrm{N}^{\mathrm{G}}$-monomethyl-L-arginine on bladder function. Eur J Pharmacol 1996;311:73-78.

60 Theobald RJ Jr: Differing effects of $\mathrm{N}^{\mathrm{G}}$ monomethyl-L-arginine and 7-nitroindazole on detrusor activity. Neurourol Urodyn 2003;22:62-69.

61 Somogyi GT, Tanowitz M, de Groat WC: M muscarinic receptor-mediated facilitation of acetylcholine release in the rat urinary bladder. J Physiol 1994;480(part 1):81-89.

62 D’Agostino G, Barbieri A, Chiossa E, Tonini M: $\mathrm{M}_{4}$ muscarinic autoreceptor-mediated inhibition of $\left[{ }^{3} \mathrm{H}\right]$ acetylcholine release in the rat isolated urinary bladder. J Pharmaco Exp Ther 1997;283:750-756.

63 Braverman AS, Kohn IJ, Luthin GR, Rugg ieri MR: Prejunctional $\mathrm{M}_{1}$ facilitory and $\mathrm{M}_{2}$ inhibitory muscarinic receptors mediate rat bladder contractility. Am J Physiol 1998;274: R517-R523.
64 D’Agostino G, Kilbinger H, Chiari MC, Grana E: Presynaptic inhibitory muscarinic receptors modulating $\left[{ }^{3} \mathrm{H}\right]$ acetylcholine release in the rat urinary bladder. J Pharmacol Exp Ther 1986;239:522-528.

65 Tobin G: Muscarinic receptor subtypes in the submandibular gland and the urinary bladder of the rabbit: in vivo and in vitro functional comparisons of receptor antagonists. J Auton Pharmacol 1995;15:451-463.

66 Takeuchi T, Yamashiro N, Kawasaki T, Nakajima H, Azuma YT, Matsui M: The role of muscarinic receptor subtypes in acetylcholine release from urinary bladder obtained from muscarinic receptor knockout mouse. Neuroscience 2008;156:381-389.

67 Tobin G, Sjogren C: Prejunctional facilitatory and inhibitory modulation of parasympathetic nerve transmission in the rabbit urinary bladder. J Auton Nerv Syst 1998;68: 153-156.

68 Miyamoto Y, Yoshida M, Takahashi W, Inadome A, Yono M, Seshita H, Murakami S, Ueda S: The effect of nitric oxide on acetylcholine release in the rabbit bladder. Eur J Pharmacol 2001;428:59-67.

69 Mattiasson A, Andersson KE, Elbadawi A, Morgan E, Sjogren C: Interaction between adrenergic and cholinergic nerve terminals in the urinary bladder of rabbit, cat and man. J Urol 1987;137:1017-1019.

70 Trendelenburg AU, Meyer A, Wess J, Starke $\mathrm{K}$ : Distinct mixtures of muscarinic receptor subtypes mediate inhibition of noradrenaline release in different mouse peripheral tissues, as studied with receptor knockout mice. Br J Pharmacol 2005; 145:1153-1159.

71 Mattiasson A, Andersson KE, Sjogren C: Adrenoceptors and cholinoceptors controlling noradrenaline release from adrenergic nerves in the urethra of rabbit and man. J Urol 1984;131:1190-1195.

72 Apodaca G: The uroepithelium: not just a passive barrier. Traffic 2004;5:117-128

73 Lewis SA: Everything you wanted to know about the bladder epithelium but were afraid to ask. Am J Physiol Renal Physiol 2000;278: F867-F874.

74 Birder LA: More than just a barrier: urothelium as a drug target for urinary bladder pain. Am J Physiol Renal Physiol 2005;289: F489-F495.

75 de Groat WC: The urothelium in overactive bladder: passive bystander or active participant? Urology 2004;64:7-11.

76 Andersson KE, Hedlund P: Pharmacologic perspective on the physiology of the lower urinary tract. Urology 2002;60:13-20, discussion 20-21.

-77 Hawthorn MH, Chapple CR, Cock M, ChessWilliams R: Urothelium-derived inhibitory factor(s) influences on detrusor muscle contractility in vitro. Br J Pharmacol 2000;129: 416-419. 
-78 Giglio D, Ryberg AT, To K, Delbro DS, Tobin G: Altered muscarinic receptor subtype expression and functional responses in cyclophosphamide induced cystitis in rats. Auton Neurosci 2005;122:9-20.

79 Bschleipfer T, Schukowski K, Weidner W, Grando SA, Schwantes U, Kummer W, Lips KS: Expression and distribution of cholinergic receptors in the human urothelium. Life Sci 2007;80:2303-2307.

-80 Mukerji G, Yiangou Y, Grogono J, Underwood J, Agarwal SK, Khullar V, Anand P: Localization of $\mathrm{M}_{2}$ and $\mathrm{M}_{3}$ muscarinic receptors in human bladder disorders and their clinical correlations. J Urol 2006; 176:367373.

81 Wakabayashi Y, Tomoyoshi T, Fujimiya M, Arai R, Maeda T: Substance P-containing axon terminals in the mucosa of the human urinary bladder: pre-embedding immunohistochemistry using cryostat sections for electron microscopy. Histochemistry 1993; 100:401-407.

82 Maggi CA: Tachykinins and calcitonin generelated peptide (CGRP) as co-transmitters released from peripheral endings of sensory nerves. Prog Neurobiol 1995;45:1-98.

83 Yokokawa K, Sakanaka M, Shiosaka S, Tohyama M, Shiotani Y, Sonoda T: Three-dimensional distribution of substance P-like immunoreactivity in the urinary bladder of rat. J Neural Transm 1985;63:209-222.

84 Gabella G, Davis C: Distribution of afferent axons in the bladder of rats. J Neurocytol 1998;27:141-155.

85 Ferguson DR, Kennedy I, Burton TJ: ATP is released from rabbit urinary bladder epithelial cells by hydrostatic pressure changes - a possible sensory mechanism? J Physiol 1997; 505(part 2):503-511.

86 Vlaskovska M, Kasakov L, Rong W, Bodin P, Bardini M, Cockayne DA, Ford AP, Burnstock G: P2X3 knock-out mice reveal a major sensory role for urothelially released ATP. J Neurosci 2001;21:5670-5677.

87 Elneil S, Skepper JN, Kidd EJ, Williamson JG, Ferguson DR: Distribution of $\mathrm{P}_{2} \mathrm{X}_{1}$ and $\mathrm{P} 2 \mathrm{X}_{3}$ receptors in the rat and human urinary bladder. Pharmacology 2001;63:120-128.

-88 Birder LA, Barrick SR, Roppolo JR, Kanai AJ, de Groat WC, Kiss S, Buffington CA: Feline interstitial cystitis results in mechanical hypersensitivity and altered ATP release from bladder urothelium. Am J Physiol Renal Physiol 2003;285:F423-F429.

-89 Kullmann FA, Artim DE, Birder LA, de Groat WC: Activation of muscarinic receptors in rat bladder sensory pathways alters reflex bladder activity. J Neurosci 2008;28: 1977-1987.

-90 Lips KS, Wunsch J, Zarghooni S, Bschleipfer T, Schukowski K, Weidner W, Wessler I, Schwantes U, Koepsell H, Kummer W: Acetylcholine and molecular components of its synthesis and release machinery in the urothelium. Eur Urol 2007;51:1042-1053.
91 Yoshida M, Inadome A, Maeda Y, Satoji Y, Masunaga K, Sugiyama Y, Murakami S: Non-neuronal cholinergic system in human bladder urothelium. Urology 2006;67: 425-430.

92 Hanna-Mitchell AT, Beckel JM, Barbadora S, Kanai AJ, de Groat WC, Birder LA: Nonneuronal acetylcholine and urinary bladder urothelium. Life Sci 2007;30:22982302 .

93 Kawashima K, Fujii T: Basic and clinical aspects of non-neuronal acetylcholine: overview of non-neuronal cholinergic systems and their biological significance. J Pharmacol Sci 2008;160(2):167-173.

$\$ 4$ Chaiyaprasithi B, Mang CF, Kilbinger H, Hohenfellner M: Inhibition of human detrusor contraction by a urothelium derived factor. J Urol 2003;170:1897-1900.

95 Inci K, Ismailoglu UB, Sahin A, Sungur A, Sahin-Erdemli I: The effect of inflammation on rat urinary bladder-dependent relaxation in coaxial bioassay system. Naunyn Schmiedebergs Arch Pharmacol 2003; 367:547-552.

96 Fovaeus M, Fujiwara M, Hogestatt ED, Persson K, Andersson KE: A non-nitrergic smooth muscle relaxant factor released from rat urinary bladder by muscarinic receptor stimulation. J Urol 1999;161:649653

$\$ 97$ Andersson M, Tobin G, Giglio D: Cholinergic nitric oxide release from the urinary bladder mucosa in cyclophosphamide-induced cystitis of the anaesthetized rat. $\mathrm{Br} \mathrm{J}$ Pharmacol 2008;153:1438-1444.

$\$ 98$ Ekstrom J, Malmberg L: On a cholinergic motor innervation of the rat urethra. Acta Physiol Scand 1984;120:237-242.

99 Slack BE, Downie JW: Pharmacological analysis of the responses of the feline urethra to autonomic nerve stimulation. J Auton Nerv Syst 1983;8:141-160.

100 Mattiasson A, Andersson KE, Andersson PO, Larsson B, Sjogren C, Uvelius B: Nervemediated functions in the circular and longitudinal muscle layers of the proximal female rabbit urethra. J Urol 1990;143: 155-160.

101 Bridgewater M, Davies JR, Brading AF: Regional variations in the neural control of the female pig urethra. Br J Urol 1995;76: 730-740.

102 Brading AF: The physiology of the mammalian urinary outflow tract. Exp Physiol 1999;84:215-221.

103 Nagahama K, Tsujii T, Morita T, Azuma H, Oshima H: Differences between proximal and distal portions of the male rabbit posterior urethra in the physiological role of muscarinic cholinergic receptors. $\mathrm{Br} \mathrm{J}$ Pharmacol 1998;124:1175-1180.

104 Kakizaki H, Fraser MO, De Groat WC: Reflex pathways controlling urethral striated and smooth muscle function in the male rat. Am J Physiol 1997;272:R1647-R1656.
105 Pinna C, Ventura S, Puglisi L, Burnstock G: A pharmacological and histochemical study of hamster urethra and the role of urothelium. Br J Pharmacol 1996;119:655-662.

106 Yoshimura N, de Groat WC: Increased excitability of afferent neurons innervating rat urinary bladder after chronic bladder inflammation. J Neurosci 1999;19:46444653.

107 Andersson KE, Arner A: Urinary bladder contraction and relaxation: physiology and pathophysiology. Physiol Rev 2004;84:935986.

108 Mok MH, Knight GE, Andrews PL, Hoyle $\mathrm{CH}$, Burnstock G: The effects of cyclophosphamide on neurotransmission in the urinary bladder of Suncus murinus, the house musk shrew. J Auton Nerv Syst 2000;80: 130-136.

109 Ekstrom J, Malmberg L: Development of supersensitivity to methacholine in the rat detrusor following either parasympathetic denervation or decentralization. Acta Physiol Scand 1984;122:175-179.

110 Malmgren A, Ekblad E, Sundler F, Andersson KE, Andersson PO: Muscarinic supersensitivity in the rat urinary bladder after capsaicin pretreatment. Acta Physiol Scand 1990;138:377-387.

-111 Braverman A, Legos J, Young W, Luthin G, Ruggieri $\mathrm{M}: \mathrm{M}_{2}$ receptors in genito-urinary smooth muscle pathology. Life Sci 1999;64: 429-436.

112 Braverman AS, Luthin GR, Ruggieri MR: $\mathrm{M}_{2}$ muscarinic receptor contributes to contraction of the denervated rat urinary bladder. Am J Physiol 1998;275:R1654-R1660.

113 Gunasena KT, Nimmo AJ, Morrison JF, Whitaker EM: Effects of denervation on muscarinic receptors in the rat bladder. $\mathrm{Br}$ J Urol 1995;76:291-296.

114 Tong YC, Cheng JT: Alteration of $\mathrm{M}_{3}$ subtype muscarinic receptors in the diabetic rat urinary bladder. Pharmacology 2002; 64:148-151.

115 Saito M, Nakamura I, Miyagawa I: Autoradiographic localization of muscarinic receptors in diabetic rat bladder (in Japanese). Nippon Hinyokika Gakkai Zasshi 1997;88: 858-867.

116 Stevens LA, Sellers DJ, McKay NG, Chapple CR, Chess-Williams R: Muscarinic receptor function, density and G-protein coupling in the overactive diabetic rat bladder. Auton Autacoid Pharmacol 2006;26:303309.

117 Giglio D: On the Autonomic Control of the Lower Urinary Tract - Functional and Morphological Changes in the Normal and the Inflamed Urinary Bladder. Göteborg, Göteborg University, 2006.

- 118 Giglio D, Andersson M, Aronsson P, Delbro DS, Haraldsson B, Tobin G: Changes in muscarinic receptors in the toad urothelial cell line TBM-54 following acrolein treatment. Clin Exp Pharmacol Physiol 2008;35: 217-222. 
119 Dickson A, Avelino A, Cruz F, Ribeiro-daSilva A: Peptidergic sensory and parasympathetic fiber sprouting in the mucosa of the rat urinary bladder in a chronic model of cyclophosphamide-induced cystitis Neuroscience 2006;141:1633-1647.

120 Giglio D, Aronsson P, Eriksson L, Tobin G: In vitro characterization of parasympathetic and sympathetic responses in cyclophosphamide-induced cystitis in the rat. Basic Clin Pharmacol Toxicol 2007; 100:96108.

121 Somogyi GT, Zernova GV, Yoshiyama M, Rocha JN, Smith CP, de Groat WC: Change in muscarinic modulation of transmitter release in the rat urinary bladder after spinal cord injury. Neurochem Int 2003;43: 73-77.

-122 Salas NA, Somogyi GT, Gangitano DA, Boone TB, Smith CP: Receptor activated bladder and spinal ATP release in neurally intact and chronic spinal cord injured rats. Neurochem Int 2007;50:345-350.

- 123 Maggi CA, Santicioli P, Meli A: Postnatal development of myogenic contractile activity and excitatory innervation of rat urinary bladder. Am J Physiol 1984;247:R972R978.

124 Tong YC, Hung YC, Shinozuka K, Kunitomo M, Cheng JT: Evidence of adenosine 5'triphosphate release from nerve and $\mathrm{P} 2 \mathrm{x}$ purinoceptor mediated contraction during electrical stimulation of rat urinary bladder smooth muscle. J Urol 1997;158:19731977.

- 125 Ambache N, Zar MA: Non-cholinergic transmission by post-ganglionic motor neurones in the mammalian bladder. J Physiol 1970;210:761-783.

126 Hukovic S, Rand MJ, Vanov S: Observations on an isolated, innervated preparation of rat urinary bladder. $\mathrm{Br} \mathrm{J}$ Pharmacol Chemother 1965;24:178-188.

- 127 Sjogren C, Andersson KE, Husted S, Mattiasson A, Moller-Madsen B: Atropine resistance of transmurally stimulated isolated human bladder muscle. J Urol 1982;128: 1368-1371.

128 Sibley GN: A comparison of spontaneous and nerve-mediated activity in bladder muscle from man, pig and rabbit. J Physiol 1984;354:431-443.

129 Burnstock G, Dumsday B, Smythe A: Atropine resistant excitation of the urinary bladder: the possibility of transmission via nerves releasing a purine nucleotide. $\mathrm{Br} \mathrm{J}$ Pharmacol 1972;44:451-461.

- 130 Moss HE, Burnstock G: A comparative study of electrical field stimulation of the guinea-pig, ferret and marmoset urinary bladder. Eur J Pharmacol 1985;114:311-316.

- 131 Bayliss M, Wu C, Newgreen D, Mundy AR, Fry CH: A quantitative study of atropineresistant contractile responses in human detrusor smooth muscle, from stable, unstable and obstructed bladders. J Urol 1999; 162:1833-1839.
132 Husted S, Sjogren C, Andersson KE: Direct effects of adenosine and adenine nucleotides on isolated human urinary bladder and their influence on electrically induced contractions. J Urol 1983;130:392-398.

133 Tagliani M, Candura SM, Di Nucci A, Franceschetti GP, D’Agostino G, Ricotti P, Fiori E, Tonini M: A re-appraisal of the nature of the atropine-resistant contraction to electrical field stimulation in the human isolated detrusor muscle. Naunyn Schmiedebergs Arch Pharmacol 1997;356:750-755.

134 Streng T, Talo A, Andersson KE: Transmitters contributing to the voiding contraction in female rats. BJU Int 2004;94:910-914.

135 Brading AF, Mostwin JL: Electrical and mechanical responses of guinea-pig bladder muscle to nerve stimulation. Br J Pharmacol 1989;98:1083-1090.

136 Lai HH, Smith CP, Munoz A, Boone TB, Szigeti GP, Somogyi GT: Activation of cholinergic receptors blocks non-adrenergic non-cholinergic contractions in the rat urinary bladder. Brain Res Bull 2008;77:420426.

137 Malmgren A, Andersson PO, Uvelius B: Bladder function in rats with short- and long-term diabetes; effects of age and muscarinic blockade. J Urol 1989;142:16081614.

138 Banks FC, Knight GE, Calvert RC, Morgan RJ, Burnstock G: Alterations in purinergic and cholinergic components of contractile responses of isolated detrusor contraction in a rat model of partial bladder outlet obstruction. BJU Int 2006;97:372-378.

139 Andersson KE: Overactive bladder - pharmacological aspects. Scand J Urol Nephrol Suppl 2002;72-81.

140 Logadottir YR, Ehren I, Fall M, Wiklund NP, Peeker R, Hanno PM: Intravesical nitric oxide production discriminates between classic and nonulcer interstitial cystitis. J Urol 2004;171:1148-1150, discussion 1150-1151.

141 Cheng K, Zimniak P, Raufman JP: Transactivation of the epidermal growth factor receptor mediates cholinergic agonist-induced proliferation of H508 human colon cancer cells. Cancer Res 2003;63:67446750.

142 Frucht H, Jensen RT, Dexter D, Yang WL, Xiao Y: Human colon cancer cell proliferation mediated by the $\mathrm{M}_{3}$ muscarinic cholinergic receptor. Clin Cancer Res 1999;5: 2532-2539.

143 Jimenez E, Montiel M: Activation of MAP kinase by muscarinic cholinergic receptors induces cell proliferation and protein synthesis in human breast cancer cells. J Cell Physiol 2005;204:678-686.

144 Blanco M, Robinson MJ: Muscarinic $\mathrm{M}_{3}$ acetylcholine receptor immunostaining in paraffin-embedded normal and neoplastic prostatic gland tissue. Ann Diagn Pathol 2004;8:333-336.
145 Sahai A, Khan MS, Arya M, John J, Singh R, Patel HR: The overactive bladder: review of current pharmacotherapy in adults. Part 1 : pathophysiology and anticholinergic therapy. Expert Opin Pharmacother 2006; 7: 509-527.

146 Hesch K: Agents for treatment of overactive bladder: a therapeutic class review. Proc (Bayl Univ Med Cent) 2007;20:307-314.

147 Epstein BJ, Gums JG, Molina E: Newer agents for the management of overactive bladder. Am Fam Physician 2006;74:20612068.

148 Kelleher CJ, Cardozo LD, Khullar V, Salvatore S: A medium-term analysis of the subjective efficacy of treatment for women with detrusor instability and low bladder compliance. Br J Obstet Gynaecol 1997;104: 988-993.

149 Herbison P, Hay-Smith J, Ellis G, Moore K: Effectiveness of anticholinergic drugs compared with placebo in the treatment of overactive bladder: systematic review. BMJ 2003;326:841-844.

150 Appell RA: Pharmacotherapy for overactive bladder: an evidence-based approach to selecting an antimuscarinic agent. Drugs 2006;66:1361-1370

151 Andersson KE, Yoshida M: Antimuscarinics and the overactive detrusor - which is the main mechanism of action? Eur Urol 2003;43:1-5.

152 Finney SM, Andersson KE, Gillespie JI, Stewart LH: Antimuscarinic drugs in detrusor overactivity and the overactive bladder syndrome: motor or sensory actions? BJU Int 2006;98:503-507.

153 Mansfield KJ, Chandran JJ, Vaux KJ, Millard RJ, Christopoulos A, Mitchelson FJ, Burcher E: Comparison of receptor binding characteristics of commonly used muscarinic antagonists in human bladder detrusor and mucosa. J Pharmacol Exp Ther 2008, E-Pub ahead of print.

154 Krejci A, Tucek S: Quantitation of mRNAs for $M_{1}$ to $M_{5}$ subtypes of muscarinic receptors in rat heart and brain cortex. Mol Pharmacol 2002;61:1267-1272.

155 Giraldo E, Martos F, Gomez A, Garcia A, Vigano MA, Ladinsky H, Sanchez de La Cuesta F: Characterization of muscarinic receptor subtypes in human tissues. Life Sci 1988;43:1507-1515.

156 Kay GG, Granville LJ: Antimuscarinic agents: implications and concerns in the management of overactive bladder in the elderly. Clin Ther 2005;27:127-138, quiz 139140.

157 Kay GG, Wesnes KA: Pharmacodynamic effects of darifenacin, a muscarinic $\mathrm{M}$ selective receptor antagonist for the treatment of overactive bladder, in healthy volunteers. BJU Int 2005;96:1055-1062.

158 Wein AJ: Pharmacological agents for the treatment of urinary incontinence due to overactive bladder. Expert Opin Investig Drugs 2001;10:65-83. 
159 Andersson KE, Appell R, Cardozo LD, Chapple C, Drutz HP, Finkbeiner AE, Haab F, Vela Navarrete R: The pharmacological treatment of urinary incontinence. BJU Int 1999;84:923-947.

160 Caulfield MP: Muscarinic receptors - characterization, coupling and function. Pharmacol Ther 1993;58:319-379.

>161 Nilvebrant L, Gillberg PG, Sparf B: Antimuscarinic potency and bladder selectivity of PNU-200577, a major metabolite of tolterodine. Pharmacol Toxicol 1997;81:169172.

162 Gillberg PG, Sundquist S, Nilvebrant L: Comparison of the in vitro and in vivo profiles of tolterodine with those of subtypeselective muscarinic receptor antagonists. Eur J Pharmacol 1998;349:285-292.

163 Ohtake A, Saitoh C, Yuyama H, Ukai M, Okutsu H, Noguchi Y, Hatanaka T, Suzuki M, Sato S, Sasamata M, Miyata K: Pharmacological characterization of a new antimuscarinic agent, solifenacin succinate, in comparison with other antimuscarinic agents. Biol Pharm Bull 2007;30:54-58.
164 Ikeda K, Kobayashi S, Suzuki M, Miyata K, Takeuchi M, Yamada T, Honda $\mathrm{K}: \mathrm{M}_{3}$ receptor antagonism by the novel antimuscarinic agent solifenacin in the urinary bladder and salivary gland. Naunyn Schmiedebergs Arch Pharmacol 2002;366: 97-103.

165 Wagg A, Wyndaele JJ, Sieber P: Efficacy and tolerability of solifenacin in elderly subjects with overactive bladder syndrome: a pooled analysis. Am J Geriatr Pharmacother 2006;4:14-24.

166 Tobin G, Ryberg AT, Gentle S, Edwards AV: Distribution and function of muscarinic receptor subtypes in the ovine submandibular gland. J Appl Physiol 2006;100:12151223.

167 Tobin G: Salivary secretion control; in Binder MD, Hirokawa N, Windhorst U, Hirsch MC (eds): Encyclopedia of Neuroscience. Heidelberg, Springer, 2008.

168 Tong YC, Cheng JT, Hsu CT: Alterations of $\mathrm{M}_{2}$-muscarinic receptor protein and $\mathrm{mRNA}$ expression in the urothelium and muscle layer of the streptozotocin-induced diabetic rat urinary bladder. Neurosci Lett 2006; 406:216-221.
169 Masuda H, Kim YT, Tyagi S, Chancellor $\mathrm{MB}$, de Miguel F, Yoshimura N: Local effects of antimuscarinics. Urol Clin North Am 2006;33:511-518, ix-x.

170 Fader M, Glickman S, Haggar V, Barton R, Brooks R, Malone-Lee J: Intravesical atropine compared to oral oxybutynin for neurogenic detrusor overactivity: a doubleblind, randomized crossover trial. J Urol 2007;177:208-213, discussion 213.

171 Pannek J, Grigoleit U, Wormland R, Goepel $\mathrm{M}$ : Intravesical therapy for overactive bladder (in German). Urologe A 2006;45:167168, 170-163.

172 Kim Y, Yoshimura N, Masuda H, de Miguel F, Chancellor MB: Antimuscarinic agents exhibit local inhibitory effects on muscarinic receptors in bladder-afferent pathways. Urology 2005;65:238-242.

173 Yokoyama O, Yusup A, Miwa Y, Oyama N, Aoki Y, Akino H: Effects of tolterodine on an overactive bladder depend on suppression of C-fiber bladder afferent activity in rats. J Urol 2005;174:2032-2036. 